\title{
Relating circulating thyroid hormone concentrations to serum interleukins- 6 and -10 in association with non-thyroidal illnesses including chronic renal insufficiency
}

\author{
Hamdy A Abo-Zenah*†1, Sabry A Shoeb ${ }^{1}$, Alaa A Sabry ${ }^{\dagger 3}$ and \\ Hesham A Ismail2
}

Address: ${ }^{1}$ Departments Of Internal Medicine, Faculty Of Medicine, Menufiya University, Egypt, ${ }^{2}$ Molecular Diagnostic Department, Genetic Engineering and Biotechnology Research Institute, Menufiya University, Egypt and ${ }^{3}$ Mansura Urology and Nephrology Institute, Mansura University, Egypt

Email: Hamdy A Abo-Zenah* - abozenahamdy@hotmail.com; Sabry A Shoeb - shoeb20@ hotmail.com; Alaa A Sabry - asabry20@yahoo.com; Hesham A Ismail - ismail5@yahoo.com

* Corresponding author †Equal contributors

Published: 22 January 2008

BMC Endocrine Disorders 2008, 8:1 doi:10.1186/1472-6823-8-1
Received: 2 June 2007

Accepted: 22 January 2008

This article is available from: http://www.biomedcentral.com/l472-6823/8/I

(c) 2008 Abo-Zenah et al; licensee BioMed Central Ltd.

This is an Open Access article distributed under the terms of the Creative Commons Attribution License (http://creativecommons.org/licenses/by/2.0), which permits unrestricted use, distribution, and reproduction in any medium, provided the original work is properly cited.

\begin{abstract}
Background: Because of the possible role of cytokines including interleukins (IL) in systemic non-thyroidal illnesses' (NTI) pathogenesis and consequently the frequently associated alterations in thyroid hormone (TH) concentrations constituting the euthyroid sick syndrome (ESS), we aimed in this research to elucidate the possible relation between IL-6 \& IL-10 and any documented ESS in a cohort of patients with NTI.
\end{abstract}

Methods: Sixty patients and twenty healthy volunteers were recruited. The patients were subdivided into three subgroups depending on their underlying NTI and included 20 patients with chronic renal insufficiency (CRI), congestive heart failure (CHF), and ICU patients with myocardial infarction (MI). Determination of the circulating serum levels of IL-6 and IL-I0, thyroid stimulating hormone (TSH), as well as total T4 and T3 was carried out.

Results: In the whole group of patients, we detected a significantly lower T3 and T4 levels compared to control subjects $(0.938$ $\pm 0.477 \mathrm{vs} \mathrm{I} .345 \pm 0.44 \mathrm{nmol} / \mathrm{L}, \mathrm{P}=0.00 \mathrm{I}$ and $47.9 \pm 28.4 \mathrm{I}$ vs $108 \pm 19.49 \mathrm{nmol} / \mathrm{L}, \mathrm{p}<0.000 \mathrm{I}$ respectively) while the TSH level was normal $(\mathrm{I} .08+0.5 \mathrm{I} 8 \mu \mathrm{lU} / \mathrm{L})$. Further, IL- 6 was substantially higher above controls' levels $(105.18 \pm 72.0 \mathrm{l}$ vs $3.35 \pm 1.18 \mathrm{ng} /$ L, $p<0.0000 \mathrm{I})$ and correlated negatively with both T3 and T4 $(r=-0.620, p<0.000 \mathrm{I} \&-0.267, p<0.00 \mathrm{I}$, respectively). Similarly was IL-I 0 level $(74 . \mathrm{I} 3 \pm 52.99$ vs $2.64 \pm 0.92 \mathrm{ng} / \mathrm{ml}, \mathrm{p}<0.0000 \mathrm{I})$ that correlated negatively with T3 $(r=-0.5 \mathrm{I} 2, \mathrm{p}<0.000 \mathrm{I})$ but not T4. Interestingly, both interleukins correlated positively $(r=0.770, p=<0.00 \mathrm{I})$. Moreover, IL-6 $\left(R^{2}=0.338, p=0.00 \mathrm{I}\right)$ and not IL-I 0 was a predictor of low T3 levels with only a borderline significance for T4 $\left(R^{2}=0.082, P=0.07 \mathrm{I}\right)$.

By subgroup analysis, the proportion of patients with subnormal T3, T4, and TSH levels was highest in the Ml patients $(70 \%$, $70 \%$, and $72 \%$, respectively) who displayed the greatest IL-6 and IL- 10 concentrations ( $192.5 \pm 45.1 \mathrm{ng} / \mathrm{L} \& 122.95 \pm 46.1 \mathrm{ng} / \mathrm{L}$, respectively) compared with CHF $(82.95 \pm 28.9 \mathrm{ng} / \mathrm{L} \& 69.05 \pm 44.0 \mathrm{ng} / \mathrm{L}$, respectively) and CRI patients $(40.05 \pm 28.9 \mathrm{ng} / \mathrm{L}$ \& $30.4 \pm 10.6 \mathrm{ng} / \mathrm{L}$, respectively). Surprisingly, CRI patients showed the least disturbance in IL-6 and IL- 10 despite the lower levels of T3, T4, and TSH in a higher proportion of them compared to CHF patients $(40 \%, 45 \%, \& 26 \%$ vs $35 \%, 25 \%, \& 18 \%$, respectively).

Conclusion: the high prevalence of ESS we detected in NTI including CRI may be linked to IL- 6 and IL-I0 alterations. Further, perturbation of IL- 6 and not IL-10 might be involved in ESS pathogenesis although it is not the only key player as suggested by our findings in CRI. 


\section{Background}

Despite absence of thyroid disease, patients with non-thyroidal illness (NTI) frequently have changes in serum thyroid hormone (TH) measurements that may suggest thyroid dysfunction. The clinical impression of euthyroidism is supported by normal serum thyroid stimulating hormone (TSH) in most of these patients [1]. Many of the clinically euthyroid patients with NTI have low circulating concentrations of total and absolute free triiodothyronine (T3), low-normal concentrations of total thyroxine (T4), elevated concentrations of absolute free T4, and normal or subnormal TSH [2] although Hesch (1981) has reported simultaneous elevation of TSH to compensate for these low levels. Consequently, the patients are usually clinically euthyroid [3]. This was named the "euthyroid sick syndrome" (ESS) [4] that have been described some 36 years ago [5].

The mechanisms accounting for such alterations in the $\mathrm{TH}$ levels in association with NTI remain unknown despite extensive investigations. The hope for the discovery of factor (s) responsible for such changes came with the observations that inflammatory cytokines are influential in systemic diseases mediation [6]. More precisely, the cytokine tumor necrosis factor- $\alpha$ (TNF- $\alpha$ ) and interleukin$1 \beta$ (IL-1 $\beta$ ) resulted in similar changes in TH concentrations in experimental animals [7] and human volunteers [8]. However, none of the two cytokines was consistently detectable NTI-patients $[9,10]$. In contrast, IL-6 is usually detectable in serum during illness and acts as a systemic hormone [11] that may mediate the well documented inhibitory effect of IL-1 on thyroid cell functions [12]. Interestingly, Shalaby and colleagues (1989) suggested IL6 as a potential factor in the pathogenesis of the ESS [13].

Although the pathogenesis of hypothalamic-pituitary-thyroid axis depression encountered in ESS remains elusive, yet it is currently agreed that it may be related to increased cytokines production $[14,11,15]$ that induced competition for limiting amounts of co-activators and decreases hepatocyte thyroxine 5' D-I deiodinase enzyme expression [16]. The inhibitory effect of IL- 6 on thyroid function may be through binding of IL-6-sIL-6R complex to gp130 [17].

In contrast to IL-6, IL-10 is one of the most potent antiinflammatory cytokines $[18,19]$ and is produced by macrophages as well as other cell types [20]. Interestingly, proinflammatory stimuli like IL-1 $\beta$ and TNF- $\alpha$ enhance its secretion without any influence of IL-6 [21].

We have carried out this cross-sectional observational study to link thyroid function and the cytokines; IL- 6 as well as IL-10 in a group of patients with ESS associated with variable NTI including chronic renal insufficiency (CRI).

\section{Methods}

We have investigated serum samples collected from 60 patients (46 men, 14 women; aged $45 \pm 19$ years) who were hospitalized because of a wide variety of NTI. The patients were recruited to the planned study consecutively in a random manner except those with known or clinically suspected thyroid dysfunction. Additional exclusion criteria were use of thyroid hormones or thyrostatic medications. The patients were subdivided into 3 equal subgroups reflecting the nature of their NTI and include; those with CRI, congestive heart failure (CHF), and patients with acute myocardial infarction (MI). None of the CRI patient was replaced by dialysis treatment as their mean estimated glomerular filtration rate, using the abbreviated 4 variable MDRD formula, was $27.6 \pm 3 \mathrm{ml} /$ $\min / 1.73 \mathrm{~m}^{2}$. The leading cause of their chronic renal insufficiency was DM (30\%), hypertension (25\%), glomerular disease $(15 \%)$, obstructive nephropathy $(10 \%)$ and unknown in the remaining $(20 \%)$. The severity of MI was assessed clinically as well as by the degree of elevation of CK-MB isoenzyme. Twenty healthy volunteers ( 15 men, 5 women; aged $39 \pm 5$ years) were recruited as control group. Samples from both patients and controls were collected for measurement of serum IL-6, IL-10, TSH, T3, and total T4 levels.

Both, the ultrasensitive human TSH (hTSH II) and free T3 were measured by a Microparticle Enzyme Immunoassay (MEIA) on AxSYM System (Abbott Laboratories, Abbott Park, USA) [22,23] while total serum T4 was measured by the Fluorescence Polarization Immunoassay (FPIA) method on AxSYM System [24] using the standard laboratory methodologies.

Serum IL-6 was measured using a commercially obtained immunoassay (IL-6 Quantikin assay, R\&D Systems, Abingdon, UK) with a sensitivity of $0.7 \mathrm{ng} / \mathrm{l}$ and an intraand inter-assay CV of 3.2 and 5.7\%, respectively. IL-6 reference values in fresh samples of healthy individuals are 20-12.5 ng/L. The serum level of IL-10 (Human IL-10 Quantikin ELISA immunoassay, R\&D Systems Inc, Minneapolis, Minnesota, USA) was measured with an expected value below $5 \mathrm{pg} / \mathrm{ml}$ and no cross-reactivity with other interleukins including IL-6. The maximum interand intra-assay CV were $9.8 \%$ and $5.6 \%$, respectively. Blood samples were taken between $7 \mathrm{AM}$ and 9 AM after an overnight fast. After centrifugation $(1500 \times \mathrm{g})$ for 10 minutes, aliquots of serum were stored at $-20^{\circ} \mathrm{C}$ until the time of sample analysis. Both interleukins were assessed by competitive enzyme-linked immunosorbent assay (ELISA) in serum of both patients' and control's according 
to a method described by Helle and colleagues (1991) using recombinant human cytokine as standard [25].

For the MI patients, the cardiac enzyme CK-MB isoenzyme was measured (IU/L) as a rough indicator of myocardial damage severity while the glomerular filtration rate was estimated (eGFR) based on the abbreviated MDRD formula:

$$
\text { eGFR }\left(\mathrm{ml} / \mathrm{min} / 1.73 \mathrm{~m}^{2}\right)=186 \times\left\{[\mathrm{sCr}]^{-1.154}\right\} \times \text { age }
$$
(years) $^{-0.203} \times 0.742$ if Female $\times 1.21$ if Black.

Where: $\mathrm{sCr}=$ serum creatinine concentration $(\mathrm{mg} / \mathrm{dl})$.

This study was approved by our local ethical committee and all the patients participated in the study after a written consent.

\section{Statistical Analysis}

Variables are given as mean and standard deviation (SD) unless otherwise stated. T-test, Kruskal-Wallis Test and Pearson correlation were used as indicated. Multivariate linear regression analysis was employed to determine the predictive value of quantitative parameters. A p value $\leq$ 0.05 was viewed as statistically significant with assignment of a borderline of significance when the $p$ value lies between $>0.05$ and $<0.1$, while a non-significant level was noted as NS. All analysis was performed using the Statistical Package for Social Science (SPSS) version 10.0.

\section{Results}

\section{Thyroid hormone levels}

We noted, as seen in table 1, a lower T3 levels in patients with NTI compared to the corresponding level in control subjects $(0.938 \pm 0.477$ vs $1.345 \pm 0.44 \mathrm{nmol} / \mathrm{L})$ that was a statistically significant $(\mathrm{p}=0.001)$. Likewise was $\mathrm{T} 4 \mathrm{con}$ centrations $(47.9 \pm 28.41$ vs $108 \pm 19.49 \mathrm{nmol} / \mathrm{L}, \mathrm{p}<$ $0.0001)$. While TSH was significantly lower in NTI patients $(1.08 \pm 0.518$ vs $1.92 \pm 0.93 \mu \mathrm{IU} / \mathrm{L}, t$ test $\mathrm{p}<$ $0.001)$, it was well within the normal reference values of employed immunoassay $(0.49+4.67 \mu \mathrm{IU} / \mathrm{L})$.

\section{Serum interleukins concentrations}

In the same table, IL- 6 in NTI was significantly above controls' level $(105.18 \pm 72.01$ vs $3.35 \pm 1.18 \mathrm{ng} / \mathrm{L}, \mathrm{p}<$ $0.00001)$. Overall, this level is considerably above the sensitivity of the used immunoassay kit and above, as well, the upper limit of normal reference value $(<20 \mathrm{pg} / \mathrm{ml})$. Similarly, IL-10 was significantly higher above measurements observed in controls $(74.13 \pm 52.99$ vs $2.64 \pm 0.92$ $\mathrm{ng} / \mathrm{ml}, \mathrm{p}<0.00001$ ). Of note, such concentrations are significantly above the upper limit of normal level of the used kit $(<5 \mathrm{pg} / \mathrm{ml})$.

Of note, in order to verify the validity of the data in view of the high level of the investigated interleukins and to assess the linearity of the assay, we diluted the samples with the appropriate Calibrator Diluent to produce samples with values within the dynamic range of the used immunoassay.

\section{Relation between thyroid hormones and interleukins changes}

We observed in NTI patients a significantly negative correlation, using Pearson' correlation coefficient, between IL6 and T3 $(r=-0.620, p<0.0001)$ (figure 1$)$. Similarly was the correlation existing between IL- 6 and total T4 level ( $\mathrm{r}$ $=-0.267, \mathrm{p}<0.001)$. Likewise, IL-10 was negatively and significantly correlated with the lowered T3 in NTIpatients $(\mathrm{r}=-0.512,<0.0001)$ (figure 1$)$ and not with $\mathrm{T} 4$ or TSH. Interestingly, both interleukins; IL-6 and IL-10 were positively and significantly correlated $(\mathrm{r}=0.770, \mathrm{p}=$ $<0.001$ ) with each other (figure 2).

By linear regression analysis, IL-6 (Unstandardized Coefficient $(B) \pm$ Standard Error $(S E)=-3.72 \mathrm{E}-03 \pm 0.001, \mathrm{R}^{2}=$ $0.338, \mathrm{p}=0.001)$ and not IL-10 (B) $\pm \mathrm{SE}=-7.512 \mathrm{E}-04 \pm$ $0.001, \mathrm{R}^{2}=0.338, \mathrm{p}=0.631$ ) was found to be a potential risk factor that could predict the observed lower circulating level of T3. However, only a borderline degree of significance $\left(B \pm S E=-0.144 \pm 0.079, R^{2}=0.082, p=0.071\right)$ was seen for IL- 6 as a potential predictor of T4 reduction in NTI. Importantly, IL-10 has not been found to be a potential predictor for the lower TH concentrations.

Table I: Comparison between serum T3, T4, TSH, IL-6 and IL-10 levels in the 60 non-thyroidal illness patients and their 20 control subjects.

\begin{tabular}{cccc}
\hline Tested Parameters & Non-thyroidal IIIness $(\mathrm{n}=60)$ & Healthy Controls $(\mathrm{n}=20)$ & Significance Level $(\mathrm{p}$ Value $)$ \\
\hline T3 $(\mathrm{n} \mathrm{mol} / \mathrm{L})$ & $0.936 \pm 0.47$ & $1.343 \pm 0.45$ & $0.00 \mathrm{I}$ \\
T4 $(\mathrm{n} \mathrm{mol} / \mathrm{L})$ & $74.90 \pm 28.41$ & $108.30 \pm 14.50$ & $<0.000 \mathrm{I}$ \\
TSH $(\mu \mathrm{I} / \mathrm{L})$ & $1.078 \pm 0.52$ & $1.921 \pm 0.93$ & $<0.00 \mathrm{I}$ \\
IL-6 $(\mathrm{ng} / \mathrm{L})$ & $105.18 \pm 72.01$ & $3.34 \pm 1018$ & $<0.0001$ \\
IL-10 $(\mathrm{ng} / \mathrm{L})$ & $74.33 \pm 52.99$ & $2.64 \pm 0.92$ & $<0.00001$
\end{tabular}

Out of the investigated 60 patients, four showed a TSH serum level that was below the sensitivity of the used assay ( $0.06 \mu \mathrm{IU} / \mathrm{L})$. These patients were assumed to have a TSH concentration of $(0.06 \mu \mathrm{lU} / \mathrm{L})$ in order to calculate the mean TSH value. 


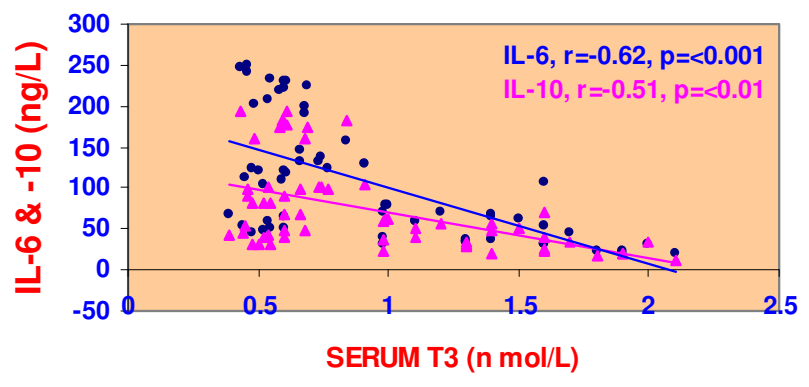

Figure I

Relations between serum T3 and both IL- 6 \& IL-I 0 in all patients with non-thyroidal illness.

\section{Subgroup analysis}

Using ANOVA single-factor test (Kruskall-Wallis test), we have detected a significant trend in T3 alterations among the three subgroups of NTI patients and their controls (p $<0.0001)$. Approximately, more or less similar level of significance do exist for total T4 $(\mathrm{p}<0.001)$. Interestingly, differences in both IL- 6 and IL-10 among the 4 subgroups were significant also $(\mathrm{p}<0.00001)$.

Further, the proportion of patients with $\mathrm{T} 3$, total $\mathrm{T} 4$, and TSH levels below normal range was highest in the MI patients $(70 \%, 70 \%$, and $72 \%$, respectively) who displayed the greatest mean concentration of both IL- 6 and IL-10 (192.5 $\pm 45.1 \mathrm{ng} / \mathrm{L} \& 122.95 \pm 46.1 \mathrm{ng} / \mathrm{L}$, respectively) compared with CHF $(82.95 \pm 28.9 \mathrm{ng} / \mathrm{L} \& 69.05 \pm$ $44.0 \mathrm{ng} / \mathrm{L}$, respectively) and CRI patients $(40.05 \pm 28.9$ $\mathrm{ng} / \mathrm{L} \& 30.4 \pm 10.6 \mathrm{ng} / \mathrm{L}$, respectively) (table 2 ). Of note, the changes in interleukins levels matched the severity of myocardial damage in MI subgroup of patients as inferred from the significant correlations observed between the cardiac enzyme CK-MB isoenzyme and both IL-6 ( $\mathrm{r}=$ 0.498 and $\mathrm{p}=0.025)$ and $\mathrm{IL}-10(\mathrm{r}=0.467$ and $\mathrm{p}=0.038)$. Surprising was our observation that CRI-patients showed

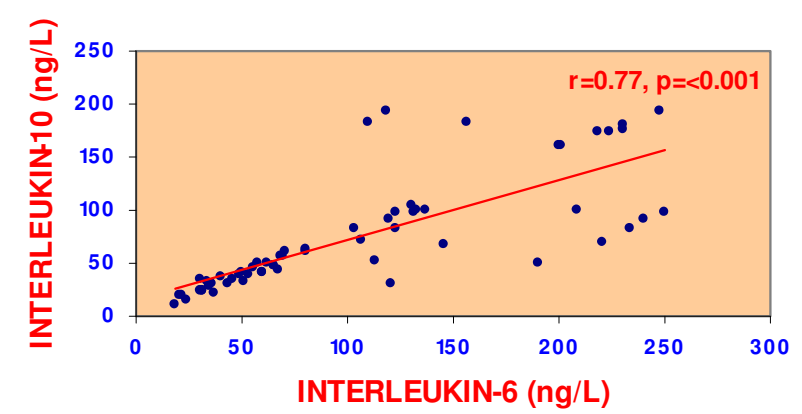

Figure 2

Correlation between IL-6 \& IL- 10 in the 60 patients with non-thyroidal illness. the least disturbance in IL- 6 and IL-10 despite the exhibition of lower than normal levels of T3, T4, and TSH in a higher proportion of them compared with CHF patients ( $40 \%, 45 \%$, and $26 \%$ versus $35 \%, 25 \%$, and $18 \%$, respectively) (table 2).

\section{Discussion}

In the current study, we observed a considerably lower T3 and total T4 concentrations signifying thyroid dysfunction in patients with variable non-thyroidal illnesses (NTI) while serum TSH showed a mean value that was not significantly different from that in controls. Our findings are in concordance with that noted by Horimoto and coworkers (1988) [26]and in contrast to the result of a study undertaken by Kayima and associates (1992) [27]. The clinically euthyroid patients, are biochemically abnormal defining the previously described euthyroid sick syndrome (ESS) $[4,28]$.

Speculations as to the value of ESS development in patients with NTI have long been heard. Some investigators reported a protective function of this phenomenon $[4,14]$ while others viewed it either as an adaptive response to reduce tissue energy requirements in face of systemic illness, or a maladaptive one, that induces damaging tissue hypothyroid [29].

Also, in the study under discussion we detected a substantially high level of the pro-inflammatory cytokine, IL-6 in NTI patients supporting its possible role as an endocrine cytokine with a regulatory effect on many endocrine systems [30], including thyroid gland [31]. We as well detected a considerably high level of the anti-inflammatory cytokine, IL-10 in NTI-patients. Likewise, Dehoux and associates (2000) reported its release in response to stressful situations such as cardiopulmonary bypass [32]. Interestingly, we noticed a positive association between both IL- 6 and IL-10 which accords with a previous notion [33] and could be attributed to the fact that secretion of both interleukins is stimulated by the same cytokines such as TNF- $\alpha[34,35]$. So, within the cytokine network, activation of pro-inflammatory mediators such as IL- 6 is followed by increased production of endogenous inhibitory molecules including the antagonistic cytokine IL-10 in an attempt to suppress release of pro-inflammatory cytokines. This dimorphic response may be related to macrophages resistance to the suppressive effect of IL-10 as a result of down-regulation of soluble IL-10 receptors expression [36]. The high IL-10 levels was hoped for to minimize the deleterious effect of the raised IL-6 [37]. Taniguchi and colleagues (1999) highlighted this potential protective effect of IL-10 in their 25 patients with systemic inflammatory states [38]. 
Table 2: Prevalence and concentrations of serum T3, T4, TSH, IL-6 and IL- 10 in the evaluated non-thyroidal illness subgroups of patients.

\begin{tabular}{cccc}
\hline VARIABLES & MI $(\mathrm{n}=20)$ & CHF $(\mathrm{n}=20)$ & CRI $(\mathrm{n}=20)$ \\
\hline T3 $(\mathrm{n} \mathrm{mol} / \mathrm{L})$ & $0.63 \pm 0.13(70 \%)$ & $1.07 \pm 0.47(35 \%)$ & $1.14 \pm 0.57(40 \%)$ \\
T4 $(\mathrm{n} \mathrm{mol} / \mathrm{L})$ & $75.65 \pm 37.57(70 \%)$ & $70.85 \pm 22.68(25 \%)$ & $78.2 \pm 23.47(45 \%)$ \\
TSH $(\mu / \mathrm{L} / \mathrm{L})$ & $1.23 \pm 0.63(72 \%)$ & $0.96 \pm 0.32(18 \%)$ & $1.04 \pm 0.54(26 \%)$ \\
IL-6 $(\mathrm{ng} / \mathrm{L})$ & $192.55 \pm 15.12$ & $82.95 \pm 18.90$ & $40.50 \pm 14.38$ \\
IL-10 $(\mathrm{ng} / \mathrm{L})$ & $122.95 \pm 46.06$ & $69.05 \pm 44.04$ & $30.4 \pm 10.57$ \\
\hline
\end{tabular}

Values in parentheses represent the percentages of patients with lower than normal concentrations of the corresponding parameter. $\mathrm{MI}=$ myocardial infarction, $\mathrm{CHF}=$ congestive heart failure and $\mathrm{CRI}=$ chronic renal insufficiency.

In this study, the suppressed THs were negatively associated with IL-6 elevations. Boelen and colleagues (1993) have observed similar correlation in their 100 patients with NTI during their first day of hospitalization [11]. However, such correlation does not exist for TSH and IL-6 and this was not surprising since TSH was maintained within the normal reference value. Also, we observed an inverse association between the high IL-10 and the suppressed TH levels, in contrast to the findings of Guillén and associates [39]. Dissimilar to IL-6, IL-10 was not indicative of the observed TH alterations. Our results do not so support any role for IL-10 in the pathogenesis of ESS. This is in concordance with what has been noticed by Boelen and colleagues (1996) [15].

We observed also a highest level of IL- 6 along with lowest measurements of both T3 and T4 in the MI patients while the least change was noticed in patients with chronic illness exemplified by CHF. This is in accordance with the hypothesis that the magnitude of TH alteration parallels the severity of the associated NTI [40-42]. Similarly, the considerably increased IL-10 in our MI patients was found to be linked, at least statistically, to the detected ESS. Such increase in IL-10 was reported to be beneficial to ICU patients through improving their outcome [43]. In fact, Kimur and co-workers (2001) have correlated the increased IL-6 and IL-10 with TH alterations in their 20 acute MI patients and the time course of both interleukins and T3 seemed to be tightly linked [44].

The least disturbance in T3, T4, and TSH levels concomitant with the lowest levels of IL- 6 and IL-10 were observed in CHF patients, yet higher than control subjects. This is more or less similar to the findings of Nishino and associates (2000) [45] as well as of Davis and colleagues (1996) although the latter however, have not tested IL-10 [46]. Surprising was our observation that T3 and T4 were considerably low in an appreciable proportion of CRI patients whilst their serum IL-6 (and IL-10) levels were of lesser elevations compared to other two subgroups. This might simply mean that while a probable contributory role for IL-6 is suggested, it is not the only factor involved in the pathogenesis of ESS encountered in some specific forms of NTI such as CRI. Our view is supported by a study done on 28 patients with CRF in 1994 [18] and another by Boelen and colleagues who found that only $28 \%$ of T3 levels variability was accounted for by the circulating IL- 6 concentrations [11].

From our observations in chronic forms of NTI, we can suggest that an acute rather than a long-lasting perturbation of IL- 6 may be involved in development of ESS. In accord with our suggestion was the work carried out by Stouthard and colleagues (1994) who tested the influence of acute compared to chronic administration of IL- 6 on TH homeostasis [47]. This was further supported by Hashimoto and associates (1995) who have demonstrated an inverse association between IL- 6 and TH in their paediatric patients with short-lived illness [48] but not in longerlasting diseases [49]. The same holds true for IL-10 that seems to be only partly involved in this process [32]. The continuation of the ESS state, as has been postulated by Docter and associates (1993) [50], would however be attributed to yet unidentified factors.

\section{Conclusion}

We can conclude that euthyroid sick syndrome occurs in many patients with a wide range of non-thyroidal illnesses in association with an appreciable perturbation in IL-6 as well as IL-10 and that its pathogenesis might be regulated by IL- 6 with possible involvement of some other, yet unrecognized, key players in some specific forms of NTI as chronic renal insufficiency.

\section{Competing interests}

The author(s) declare that they have no competing interests.

\section{Authors' contributions}

HHAZ initiated the idea of the study, participated in its design, performed the statistical analysis of the results, participated in the coordination and drafted the manuscript. He is the corresponding author of the paper. 
AAS participated in study design, performed the statistical analysis of the results, participated in the coordination and helped to draft the manuscript.

SAS conceived of the study and participated in the sequence alignment and helped to draft the manuscript.

All authors have read and approved the final version of the manuscript.

\section{Acknowledgements}

The authors as well would like to thank Miss Linda Dudgale who improved the quality of the written English by her assistance with language fluency and grammar checking for of this paper.

\section{References}

I. Tibaldi JM, Surks MI: Effects of non-thyroidal illness on thyroid function. Med Clin North Am 1985, 69:899-9II.

2. Carter JN, Eastmen CJ, Corcoran JM, Lazarus L: Inhibition of conversion of thyroxine to triiodothyronine in patients with severe chronic illness. Clin Endocrinol (Oxf) 1976, 5:587-594.

3. Hesch RD, ed: The low T3 syndrome. proceedings of the Serono symposia, 40, Academic Press, New York; 1981:1.

4. Wartofsky I, Burman KD: Alterations in thyroid function in patients with systemic illnesses: the "euthyroid sick syndrome". Endocrine Review 1982, 3:164-217.

5. Faber J, Kirkegaard C, Lumholtz IB, Nielsen KS, Friis T: Variations in serum T3, sT3, 3,30-diiodothyronine and 3,5-diiodothyronine induced by acute myocardial infarction and propranolol. Acta Endocrinologica 1980, 94:341-345.

6. Dinarello CA, Mier JW: Lymphokines. N Eng J Med 1987, 3 17:940-945.

7. Hermus AR, Sweep CG, Van der Meer MJ, Ross HA, Smals AG, Benraad TJ, Kloppenborg PW: Continuous infusion of interleukin I$\beta$ induces a nonthyroidal illness syndrome in the rat. Endocrinol |992, |3 |:2139-2|49.

8. Van der Poll T, Romijn JA, Wiersinga WM, Sauerwein HP: Tumor necrosis factor: a putative mediator of the sick euthyroid syndrome. J Clin Endocrinol Metab 1990, 7 I: I567-1572.

9. Mooradian AD, Reed RL, Osterweil D, Schiffman R, Scuderi P: Decreased serum triiodothyroinin is associated with increased concentrations of tumor necrosis factor. J Clin Endocrinol Metabol 1990, 71:1239-1242.

10. Chopra IJ, Sakane S, Teco GN: A study of the serum concentration of tumor necrosis factor-alpha in thyroidal and nonthyroidal illnesses. J Clin Endocrinol Metab 1991, 72: I I I3- I I I6.

II. Boelen A, Platvoet-Ter Schiphorst MC, Wiersinga WM: Association between serum interleukin-6 and serum 3,5,3'-triiodothyronine in nonthyroidal illness. I Clin Endocrinol Metab 1993, 77:1695-1699.

12. Rasmussen AK, Feldt-Rasmussen $U$, Bendtzen $K$ : The effect of interleukin-I on the thyroid gland. Autoimmunity 1993, 16:14I-148.

13. Shalaby MR, Waage A, Aarden L, Espevik T: Endotoxin, tumor necrosis factor- $\alpha$ and interleukin- $I$ induce interleukin- 6 production in vivo. Clin Immunol and Immunopathol 1989, 53:488-498.

14. De Groot LJ: Dangerous dogmas in medicine: The nonthyroidal illness syndrome. J Clinical Endocrinol and Metab 1999, 84: $151-164$.

15. Boelen A, Maas MAW, Lowik CWGM, Platvoet MC, Wiersinga WM: Induced illness in interleukin-6 (IL-6) knockout mice: A causal role of IL-6 in the development of the low 3,5,30-triiodothyronine syndrome. Endocrinol 1996, I37:5250-5254.

16. Yu J, Koenig RJ: Regulation of hepatocyte thyroxine 5'-deiodinase by T3 and nuclear receptor coactivators as a model of the sick euthyroid syndrome. I Biol Chem 2000, 275:38296-38230I.

17. Yamazaki K, Yamada E, Kanaji Y, Shizume K, Wang DS, Maruo N, Obara T, Sato K: Interleukin-6 (IL-6) inhibits thyroid function in the presence of soluble IL-6 receptor in cultured human thyroid follicles. Endocrin 1996, 137:4857-4863.
18. Bartalena L, Brogioni S, Grasso L, Velluzzi F, Martino E: Relationship of the increased interleukin-6 concentration to changes of thyroid function in nonthyroidal illness. Journal of Endocrinol Invest 1994, 17:269-274.

19. van Haasteren GA, van der Meer MJ, Hermus AR, Linkels E, Klootwijk W, Kaptein E, van Toor H, Sweep CG, Visser TJ, de Greef W]: Different effects of continuous infusion of interleukin- $I$ and interleukin-6 on the hypothalamic-hypophysial-thyroid axis. Endocrinol | 994, I 3 I: | 336-1345.

20. Hamilton TA, Ohmori Y, Tebo JM, Kishore R: Regulation of macrophage gene expression by pro- and anti-inflammatory cytokines. Pathobiology 1999, 67:24I-244.

21. Berger S, Siegert A, Denkert C, Kobel M, Hauptmann S: Interleukin10 in serous ovarian carcinoma cell lines. Cancer Immunol Immunother 200I, 50:328-333.

22. Spencer CA, LoPresti JS, Patel A, Guttler RB, Eigen A, Shen D, Gray D, Nicoloff JT: Application of a New chemiluminometric thyrotropin assay to cubnormal measurement. J Clin Endocrinol Metab 1990, 70:453-460.

23. Hay ID, Bayer MF, Kaplan MM, Klee GG, Larsen RR, Spencer CA American thyroid association assessment of current free thyroid hormone and thyrortopin measurements and guidelines for future clinical assays. Clinical Chem 1991, 37:2002-2008.

24. Felig P, Baxter JD, Broadus AE, Frohman LA, editors: Endocrinology and Metabolism (2nd ed.). New York: McGraw-Hill Book Co; 1987:389-409.

25. Helle M, Boeije L, Degroot E, Devos A, Aarden L: Sensitive ELISA for IL-6-detection of IL-6 in biological fluids, synovial fluids and sera. J Immunol Methods I99I, I38:47-56.

26. Horimoto $M$, Nishikawa $M$ : Studies on the pituitary and thyroid function in patients with nonthyroid illnesses. Nippon Naibunpi Gakkai Zasshi 1988, 64:119-127. Abstract

27. Kayima JK, Otieno LS, Gitau W, Mwai S: Thyroid hormone profiles in patients with chronic renal failure on conservative management and regular haemodialysis. East Afr Med J 1992, 69:333-336.

28. Kantrowitz LB, Peterson ME, Melian C, Nichols R: Serum total thyroxine, total triiodothyronine, free thyroxine, and thyrotropin concentrations in dogs with nonthyroidal disease. J Am Vet Med Assoc 200I, 21 9:765-769.

29. Mclver B, Gorman CA: Euthyroid sick syndrome: an overview. Thyroid 1997, 7:125-132.

30. Jones TH: Interleukin-6. Proceedings of the serono symposia, 40, Academic Press, New York; 1994.

31. Rasmussen AK, Kayser L, Feldt-Rasmussen U, Beck K, Bendtzen K, Diamant M, Perrild H: Interleukin-6 is not a secondary mediator of interleukin- $I$ induced suppression of thyroid function in cultured human thyrocytes. Exper Clin Endocrinol |99|, 97:|79-|8|.

32. Dehoux MS, Hernot S, Asehnoune K, Boutten A, Paquin S, LeconMalas V, Toueg ML, Desmonts JM, Durand G, Philip I: Cardiopulmonary bypass decreases cytokine production in lipopolysaccharide-stimulated whole blood cells: roles of interleukin- 10 and the extracorporeal circuit. Crit Care Med 2000, 28: $172 \mid-1727$.

33. Boelen A, Platvoet-Ter-Schiphorst MC, Bakker O, Wiersinga WM The roles of cytokines in the lipopolysaccharide-induced sick euthyroid syndrome in mice. J Endocrinol 1995, 146:475-483.

34. Halawa B, Salomon P, Jolda-Mydlowska B, Zysko D: Levels of tumor necrosis factor (TNF-alpha) and interleukin 6 (IL-6) in serum of patients with acute myocardial infarction. Pol Arch Med Wewn 1999, 101:197-203. Abstract

35. Schwacha MG, Schneider CP, Bland KI, Chaudry IH: Resistance of macrophages to the suppressive effect of interleukin- 10 following thermal injury. Am J Physiol Cell Physiol 200I, 281:CII80-CII87.

36. Majetschak M, Borgermann J, Waydhas C, Obertacke U, Nast-Kolb $D$, Schade FU: Whole blood tumor necrosis factor-alpha production and its relation to systemic concentrations of interleukin 4 , interleukin 10 , and transforming growth factorbetal in multiply injured blunt trauma victims. Crit Care Med 2000, 28:1847-1853.

37. Van der Poll T, Jansen PM, Montegut WJ, Braxton CC, Calvano SE, Stackpole SA, Smith SR, Swanson SW, Hack CE, Lowry SF, Moldawer LL: Effects of IL- 10 on systemic inflammatory responses dur- 
ing sublethal primate endotoxemia. I Immunol 1997, I 58:197I-1975.

38. Taniguchi T, Koido Y, Aiboshi J, Yamashita T, Suzaki S, Kurokawa A: Change in the ratio of interleukin-6 to interleukin- 10 predicts a poor outcome in patients with systemic inflammatory response syndrome. Crit Care Med 1999, 27:1262-1264.

39. Guillen I, Blanes M, Gomez-Lechon MJ, Castell JV: Cytokine signaling during myocardial infarction: sequential appearance of IL-I beta and IL-6. Am J Physiol 1995, 269:229-235.

40. Kaptein EM: The effects of systemic illness on thyroid hormone metabolism. In Thyroid Hormone Metabolism: regulation and Clinical Implications. Edited by: Wu SY. Blackwell Science, Oxford; 1991:21 1-37.

4I. Kucharz EJ, Wilk T: Dynamics of serum interleukin-6 level in patients with acute myocardial infarction. Eur J Intern Med 2000, II:253-256.

42. Kanda T, Inoue M, Kotajima N, Fujimaki S, Hoshino Y, Kurabayashi M, Kobayashi I, Tamura J: Circulating interleukin-6 and interleukin6 receptors in patients with acute and recent myocardial infarction. Cardiology 2000, 93:191-196.

43. Simovic MO, Bonham MJ, Abu-Zidan FM, Windsor JA: Anti-inflammatory cytokine response and clinical outcome in acute pancreatitis. Crit Care Med 1999, 27:2662-2665.

44. Kimur T, Kotajima N, Kanda T, Kuwabara A, Fukumura Y, Kobayashi I: Correlation of circulating interleukin- 10 with thyroid hormone in acute myocardial infarction. Res Commun Mol Pathol Pharmacol 200I, I 10:53-58.

45. Nishino M, Kimura T, Kanda T, Kotajima N, Yoshida A, Kuwabara A, Tamama K, Fukumura Y, Kobayashi I: Circulating interleukin-6 significantly correlates to thyroid hormone in acute myocardial infarction but not in chronic heart failure. J Endocrinol Invest 2000, 23:509-5I4.

46. Davies PH, Black EG, Sheppard MC, Franklyn JA: Relation between serum interleukin- 6 and thyroid hormone concentrations in 270 hospital in-patients with non-thyroidal illness. Clin Endocrinol 1996, 44: 199-205.

47. Stouthard JM, van der Poll T, Endert E, Bakker PJ, Veenhof $\mathrm{CH}$, Sauerwein HP, Romijn JA: Effects of acute and chronic interleukin6 administration on thyroid hormone metabolism in humans. J Clin Endocrinol Metab 1994, 79: I342-1346.

48. Hashimoto $H$, Igarashi $N$, Miyawaki $T$, Sato $T$ : Effect of tumor necrosis factor $\alpha$, interleukin- $I \beta$, and interleukin- 6 on type I-5-deiodination in rat thyroid cell line, FRTL-5. J Interferon and Cytokine Research 1995, 15:367-375.

49. Hashimoto H, Igarashi N, Yachie A, Miyawaki T, Hashimoto T, Sato $\mathrm{T}$ : The relationship between serum levels of interleukin- 6 and thyroid hormone during the follow-up study in children with nonthyroidal illness: marked inverse correlation in Kawasaki and infectious disease. Endocrinol J 1996, 43:3 I-38.

50. Docter R, Krenning EP, de Jong M, Hennemann G: The sick euthyroid syndrome: Changes in thyroid hormone serum parameters and hormone metabolism. Clic Endocrinol 1993, 39:499-518.

\section{Pre-publication history}

The pre-publication history for this paper can be accessed here:

http://www.biomedcentral.com/1472-6823/8/1/prepub

\section{Publish with Biomed Central and every} scientist can read your work free of charge

"BioMed Central will be the most significant development for disseminating the results of biomedical research in our lifetime. "

Sir Paul Nurse, Cancer Research UK

Your research papers will be:

- available free of charge to the entire biomedical community

- peer reviewed and published immediately upon acceptance

- cited in PubMed and archived on PubMed Central

- yours - you keep the copyright
Biomedcentral 